Електронне наукове фахове видання "Ефективна економіка" включено до переліку

наукових фахових видань України з питань економіки

(Наказ Міністерства освіти і науки України від 29.12.2014 № 1528)

www. economy.nayka.com. ua | № 5, 2019 | 30.05.2019 p.

DOI: $\underline{10.32702 / 2307-2105-2019.5 .14}$

УДК 338.246:[614.215+338.487]

В. В. Гуменюк,

доктор економічних наук, професор кафедри туризму,

Івано-Франківський національний технічний університет нафти і газу

ORCID: 0000-0002-8493-4470

\title{
ЕКОНОМІЧНА БЕЗПЕКА КУРОРТНО-РЕКРЕАЦІЙНОГО ТУРИЗМУ
}

\author{
V. Humeniuk \\ Doctor of Science in Economics, Professor of Tourism Department, \\ Ivano-Frankivsk National Technical University of Oil and Gas, Ukraine \\ ECONOMIC SECURITY OF RESORT AND RECREATIONAL TOURISM
}

Метою проведеного дослідження є розробка концептуальних положень $i$ формулювання практичних рекомендачій, спрямованих на розвиток методологічних засад управління економічною безпекою курортно-рекреаційного туризму. На основі наявних теоретичних положень, виявлення сутнісних характеристик, особливостей, систематизації отриманих результатів дослідження запропоновано концептуальні підходи до інтерпретації економічної безпеки курортно-рекреаційного туризму як сукупності достатніх та необхідних умов для належного відтворення й розвитку людського капіталу й реалізаиіі саморегулятивного потенціалу ринку курортно-рекреаційних послуг. Розкрито методологічні аспекти моніторингу економічної безпеки курортно-рекреаційної сфери, щэо, на відміну від існуючих розробок $і$ рекомендачій, передбачають виявлення розширеного спектру потенційних загроз розвитку курортної рекреачії, врахування чинників безпеки курортно-рекреаційного туризму, що дозволить розробляти системні стабілізаційні заходи державного регулювання курортно-рекреаційної сфери. Основні наукові положення статті можна використовувати у практиці державного та регіонального управління курортнорекреаційним туризмом.

The aim of the research is the development of conceptual statements and formulation of the practical recommendations aimed at the development of the methodological bases of management of the economic security of the resort and recreational tourism. The main scientific results, which are in this publication, have been obtained with the usage of the general scientific, and special methods of research (analysis and synthesis, systematization, generalization...), the interconnection of the researched facts and realities of the existing practice (estimation of the economic security of the resort and recreational tourism), scientific experiment (determination of the hypothesis of the economic security of the resort and recreational tourism). On the basis of the existing theoretical statements, discovering of essential characteristics, peculiarities, systematization of the obtained results of the research, there have been suggested the conceptual approaches to the interpretation of the economic security of the resort and recreational tourism as a complex of sufficient and necessary conditions for the appropriate reproduction and development of human capital and 
realization of the self-regulating potential of the resort and recreational services market. Practical importance of the research results. There have been shown the methodological aspects of monitoring of the economic security of the resort and recreational sphere, which, unlike the already existing works and recommendations, foresee the discovery of an expanded spectrum of potential threats for the development of the resort recreation, consideration of the resort and recreational tourism security factors, what is going to let us develop systemic measures of stabilization of the state regulation of the resort and recreational sphere. The main scientific statements of the article can be used in the practice of the state and regional management of the resort and recreational tourism.

Ключові слова: державне регулювання; економічна безпека; національна безпека; туризм; курортно-рекреаційна сфера.

Keywords: state regulation; economic security; national security; tourism; resort and recreational sphere.

Постановка проблеми. 3 проблемою падіння туристичного попиту внаслідок ризиків тероризму, дестабілізації суспільно-політичної ситуації тією чи іншою мірою стикалися багато країн світу. За даними SSFорганізації, яка моніторить безпеку туристичних подорожей в 192 країнах світу, найбільшу тривогу і застереження для організації туристичної діяльності у 2014-2018 роках викликали подорожі до Єгипту, Ізраїлю, Палестини, Тунісу, Туреччини, а також Франції (окрім, звичайно, Афганістану, Іраку, Сирії, Сомалі) [1].

У найбільш подібній до України ситуації перебувала Грузія (проблеми залучення інвестицій у розвиток курортно-рекреаційної інфраструктури, низька ефективність державного регулювання економіки, падіння туристичного попиту, політична нестабільність, ризики ескалації збройного конфлікту). Однак, володіючи значним природно-рекреаційним потенціалом для розвитку туризму і курортів, і незважаючи на тимчасову окупацію частини своєї території внаслідок воєнної агресії Російської Федерації у 2008 р. (Абхазія і Південна Осетія), ця країна зуміла провести ефективні реформи в системі державного регулювання економіки, стабілізувати суспільно-політичну ситуацію, відновити туристичну привабливість і забезпечити формування тенденції сталого економічного зростання курортно-рекреаційної сфери.

Аналіз останніх досліджень і публікацій. Методологічні аспекти дослідження економічної безпеки підприємницьких структур, концептуальні підходи до іiі оцінювання, моніторингу, контролю й управління в умовах структурно-інституційної трансформації внутрішнього ринку, розвитку сфери послуг, туризму і курортів знайшли відображення у працях А. Мазаракі, В. Лагутіна [2], С. Мельниченко [3], О. Тищенка [4], Н. Ушенко [5], I. Черниш [6] та інших науковців.

Формування цілей статті (постановка завдання). Враховуючи актуальність проблеми та необхідність iii спеціального розкриття відповідно до окресленого напряму наукових розвідок, цілями даної статті $\epsilon$ удосконалення концептуальних підходів з виявлення та систематизації чинників безпеки курортно-рекреаційної сфери; оцінювання розширеного спектру потенційних загроз економічній безпеці курортно-рекреаційного туризму; формулювання перспективних пропозицій з розробки інструментарію гарантування безпеки курортнорекреаційного туризму.

Виклад основного матеріалу дослідження 3 повним обгрунтуванням отриманих наукових результатів. Курортно-рекреаційний туризм і пов'язаний із ним сектор послуг останнім часом стрімко розвиваються в Свропейському Союзі, проте трансформаційні процеси в національній економіці, зумовлені геополітичними чинниками і внутрішніми проблемами публічного управління й адміністрування, породжують нові загрози й ризики безпеки курортно-рекреаційної сфери як інтегральної складової національної безпеки України.

Курортно-рекреаційний туризм є видом інтегрованої соціально-економічної активності, що передбачає різноманітне поєднання принципів платності та умовно безкоштовного освоєння курортно-рекреаційного простору, реалізується у формах самофінансування придбання послуг відповідно до потреб, уподобань, медичних рекомендацій, чинників купівельної спроможності, схильності до споживання, готовності оплачувати, туристичної мобільності, самодіяльного відпочинку й оздоровлення 3 використанням переважно загальнодоступних природно-лікувальних факторів; соціального трансферу оздоровчих програм, комплексу лікувальних процедур, послуг курортної реабілітації на користь споживача-бенефіціара відповідно до лікарських призначень, соціальних гарантій, зобов'язань та соціальних ініціатив працедавців. Розвиток внутрішнього та в’їзного курортно-рекреаційного туризму дуже тісно пов'язаний із проблеми гарантування національної безпеки країни.

Національна безпека, відповідно до Закону України «Про основи національної безпеки України» від 19.06.2003 № 964-IV, розглядається, по-перше, як захищеність життєво важливих інтересів людини, по-друге, як 
така, за якої забезпечується сталий розвиток суспільства; по-третє, своєчасне виявлення, запобігання i нейтралізація реальних та потенційних загроз національним інтересам у таких сферах державного управління, як охорона здоров'я, соціальна політика, підприємницька діяльність, використання надр, земельних та водних ресурсів [7].

На різних етапах суспільно-економічного розвитку України розроблено й модифіковано декілька варіантів стратегії національної безпеки. Перший базовий іiі варіант був сформульований ще на фоні резонансних подій 2004 р., однак лише у 2007 р., відповідно до Указу Президента України від 12.02.2007 р. № 105/2007, прийнята Стратегія національної безпеки України, яка згодом у 2012 р. була представлена в новій конфігурації, відповідно до Указу Президента України від 08.06.2012 р. № 389/2012, у форматі «Стратегії національної безпеки України у світі, що змінюється». Модифікований варіант «Стратегії національної безпеки» втратив чинність 29.05.2015 р. у зв'язку з необхідністю врахування нових викликів національній безпеці, зумовлених насамперед впливом геополітичних чинників на суспільно-економічний розвиток України [8].

Відповідно до перспективного варіанту «Стратегії національної безпеки України», яка затверджена Указом Президента України від 26 травня 2015 р. №287/2015, визначено основні напрями державної політики формування економічної безпеки до 2020 р., які мають безпосереднє відношення до розв'язання проблем стабілізації курортно-рекреаційної сфери й відновлення економічної безпеки ії функціонування, зокрема:

- демонополізації і дерегуляції економіки, захисту економічної конкуренції, спрощення й оптимізації системи оподаткування, формування сприятливого бізнес-клімату та умов для прискореного інноваційного розвитку;

- ефективного застосування механізму спеціальних економічних та інших обмежувальних заходів (санкцій), унеможливлення контролю стратегічних галузей капіталом держави-агресора;

- створення найкращих у Центральній і Східній Свропі умов для інвесторів, залучення іноземних інвестицій як інструменту забезпечення національної безпеки;

- створення умов для подолання бідності і надмірного майнового розшарування в суспільстві, наближення соціальних стандартів до рівня держав Центральної і Східної Європи - членів ЄС, досягнення економічних критеріїв, необхідних для набуття Україною членства в СС [9].

Взаємозв'язок чинників економічної безпеки курортно-рекреаційної сфери відображено на рис. 1.

Своєрідним барометром суспільно-економічного розвитку кожної країни $\epsilon$ рівень розвитку платоспроможних потреб людини. Сформувати ефективний ринок курортно-рекреаційних послуг неможливо без створення платоспроможного попиту, що узгоджується з потребами оздоровлення й відпочинку споживачів.

За даними звіту міжнародної компанії GfK «Купівельна спроможність Свропи 2015/2016», індикатор купівельної спроможності населення в Україні становив у розрахунку на одну особу 978 євро на рік (аналогічний показник для порівняння - в Болгарії - 3743 євро; Румунії - 3743 євро; Польщі - 6437 євро; Австрії - 22067 євро ...) - це останнє місце в рейтингу серед 42 європейських країн. Зазначений показник майже у 14 разів менший, ніж у розрахунку на одного жителя в середньому по Європі - 13636 євро [10]. 


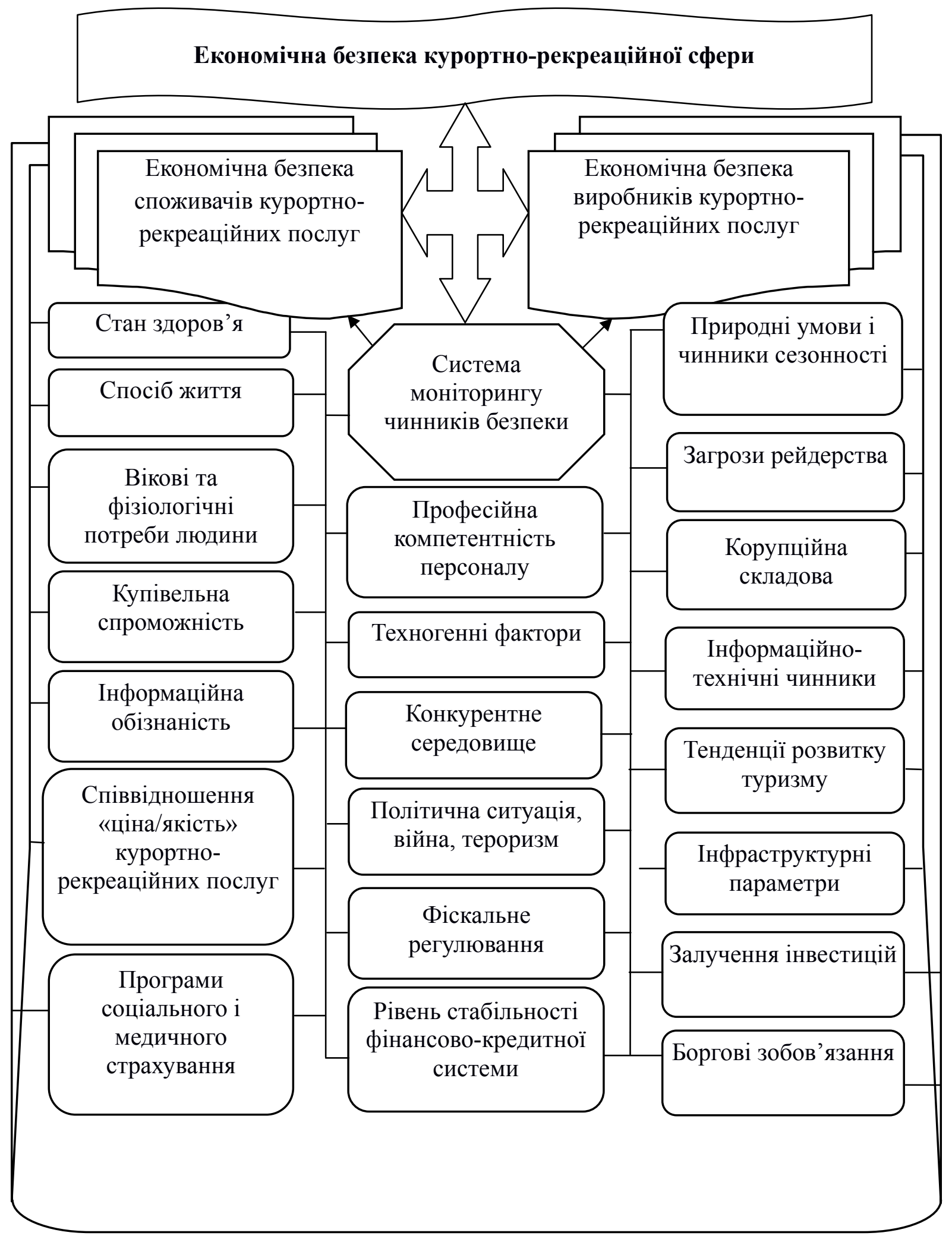

Рис. 1. Параметри економічної безпеки курортно-рекреаційного туризму Джерело: розроблено автором

3 цього приводу М. Портер зауважив, що доти, поки країна не досягне визначеного рівня доходу і національного добробуту, головна проблема, яка стоїть перед нею, не перехід в стадію багатства, а поступовий відкат назад [11, с. 746].

Сучасний стан курортно-рекреаційної сфери України є нестабільним та нестійким: падіння рівня суспільного добробуту i зниження купівельної спроможності населення на тлі загального росту цін, внутрішньополітичні проблеми стримування економічного розвитку поєднується 3 геополітичними ускладненнями та їх наслідками:

- низька ефективність адміністративних методів державного регулювання;

- територіальна близькість до тимчасово окупованих територій;

- низький рівень упровадження інновацій; 
- проблематичність стандартизації та міжнародної сертифікації курортно-рекреаційних послуг;

- слабка інтеграція та кооперація з міжнародним туристичним бізнесом, низька ділова активність туристичного посередництва в курортно-рекреаційній сфері;

- невідповідність зростання цін на курортно-рекреаційні послуги динаміці платоспроможних потреб внутрішніх споживачів;

- низький рівень конкуренції між виробниками курортно-рекреаційних послуг.

Висновки із зазначених проблем і перспективи подальших досліджень. Отже, гарантування національної безпеки в умовах формування постіндустріального суспільства вимагає підвищення якості й рівня життя людини, що виражається в стані ії здоров'я, доброго самопочуття, соціальній активності, продуктивності праці.

Стимулювання росту зайнятості і доходів населення є важливими проблемами національної безпеки, адже чим менша зайнятість і нижчий рівень реальних доходів населення, тим більш розвинуті у суспільстві патерналістські настрої, і тим масштабнішими мають бути соціальні трансферти.

Державне регулювання через вдосконалення законодавчої і нормативно-правової бази у сфері оподаткування туристичної діяльності та здійснення ефективного бюджетного фінансування туристичної галузі повинно стати дієвим засобом фінансово-економічної стабілізації туристичної галузі та переходу до економічного зростання [12, с. $15-16]$.

У зв'язку з необхідністю підвищення ефективності державної соціальної політики на ринку курортнорекреаційних послуг у контексті зміцнення соціально-економічної безпеки курортно-рекреаційного туризму потребує заміни практика формальних компенсаційних виплат за ненадані соціальні послуги громадян, які віднесені до пільгових категорій, на реальне адресне субсидіювання й реамбурсацію витрат споживачів курортно-рекреаційних послуг. Закріплення необхідного мінімуму курортно-рекреаційних послуг у споживчому кошику i формування споживчого бюджету українця 3 урахуванням норми щорічного відпочинку й оздоровлення узгоджується з напрямами вдосконалення соціальної політики України в контексті інтеграції до $\mathrm{EC}[13$, c. 25$]$.

У контексті підвищення ефективності державного регулювання економіки доцільно щорічно проводити моніторинг економічної безпеки курортно-рекреаційної сфери як у загальнонаціональному масштабі, так і на локальному рівні з урахуванням проблемних аспектів сучасного стану й потенціалу розвитку курортнорекреаційного туризму в перспективі.

\section{Література.}

1. Expert analysis of the situation in high-risk areas in 192 countries... Scutum Security First. Retrieved from https://www.securite-sf.com/?p_code=anal

2. Mazaraki A., Lagutin V. Domestic market of Ukraine in an unstable global economy// Herald of Kyiv National University of Trade and Economics. 2014. №6. P. 9-24.

3. Melnychenko S. Health resort enterprises: between stagnation and modernization // Herald of Kyiv National University of Trade and Economics. 2013. №6. P.57-67.

4. Тищенко О.П. Курортно-рекреаційна сфера України: стан, втрати, шляхи санації // Економіка і суспільство. 2016. № 6. С. 93-100.

5. Ушенко Н.В. Антикризова парадигма використання потенціалу сучасного туризму // Вісник Бердянського університету менеджменту і бізнесу. 2015. № 3. С. 29-33.

6. Черниш I.В. Формування антикризової політики держави у туризмі: монографія. Полтав. нац. техн. ун-т ім. Юрія Кондратюка. Полтава: АСMI, 2014. 586 с.

7. Про основи національної безпеки України: Закон України від 19.06.2003 № 964-IV, редакція від 07.08.2015. Режим доступу: http://zakon5.rada.gov. ua/laws/show/964-15

8. Про стратегію національної безпеки України: Указ Президента України: від 12.02.2007 № 105/2007, поточна редакція - втрата чинності від 29.05.2015 на підставі 287/2015. Режим доступу: http://zakon3.rada.gov.ua/ laws/show/105/2007

9. Про рішення Ради національної безпеки і оборони України від 6 травня 2015 року „Про Стратегію національної безпеки України: Указ Президента України: від 26.05.2015 № 287/2015”. Режим доступу: http://zakon3.rada.gov.ua/ laws/show/287/2015

10. GFK PURCHASING POWER EUROPE, 2015/2016. Available: http:// www.gfk.geomarketing.com/en/market_data/market_data_by_country/ukraine.html

11. Портер М. Международная конкуренция. Москва. Международные отношения, 1993. 896 с.

12. Гуменюк В.В. Фінансове забезпечення суб'єктів господарювання туристичної галузі. Автореферат дисертації кандидата економічних наук: 08.04.01 - фінанси, грошовий обіг і кредит. Тернопільський державний економічний університет. Тернопіль, 2006. 20 с.

13- Гуменюк В.В. Державне регулювання ринку курортно-рекреаційних послуг. Автореферат дисертації доктора економічних наук: 08.00 .03 - економіка та управління національним господарством. Київський національний торговельно-економічний університет. Київ, 2017, 40с. 


\section{References.}

1. Scutum Security First (2018), "Expert analysis of the situation in high-risk areas in 192 countries...", available at: https://www.securite-sf.com/?p_code=anal (Accessed 25 April 2019).

2. Mazaraki A. and Lagutin V. (2014), "Domestic market of Ukraine in an unstable global economy ", Herald of Kyiv National University of Trade and Economics, vol.6, pp. 9-24.

3. Melnychenko, S. (2013), "Health resort enterprises: between stagnation and modernization ." Herald of Kyiv National University of Trade and Economics, vol.6, pp. 57-67.

4. Tyshchenko, O. (2016), "Kurortno-rekreatsiyna sfera Ukrayiny: stan, vtraty, shlyakhy sanatsiyi” [Resort and recreation sphere of Ukraine: condition, losses, ways of sanation] Ekonomika i suspil'stvo, vol.6, pp. 93-100.

5. Ushenko, N. (2015), “Anti-crisis paradigm of using the potential of modern tourism”, Visnyk Berdyans'koho universytetu menedzhmentu i biznesu, vol.3, pp. 29-33.

6. Chernysh, I. (2014), Formuvannya antykryzovoyi polityky derzhavy u turyzmi [Formation of anti-crisis policy of the state in tourism], ASMI, Poltava, Ukraine.

7. Verkhovna Rada of Ukraine (2015), Law of Ukraine "On the Fundamentals of National Security of Ukraine", available at: http://zakon5.rada.gov.ua/laws/show/964-15 (Accessed 25 April 2019).

8. President of Ukraine (2015), Decree "About the strategy of national security of Ukraine", available at: http://zakon3.rada.gov.ua/ laws/show/105/2007 (Accessed 25 April 2019).

9. President of Ukraine (2015), Decree "On the decision of the National Security and Defense Council of Ukraine dated May 6, 2015 "On the Strategy of National Security of Ukraine", available at: http://zakon3.rada.gov.ua/laws/show/287/2015 (Accessed 25 April 2019).

10. GFK PURCHASING POWER EUROPE (2017), available at: http://www.gfk.geomarketing.com/en/market_data/market_data_by_country/ukraine.html (Accessed 25 April 2019).

11. Porter, M. (1993), Mezhdunarodnaia konkurentsyia [International competition], Mezhdunarodnye otnoshenyia, Moscow, Russia.

12. Humeniuk, V.V. (2006), "Financial Providing of Tourism Industry Subjects", Ph.D. Thesis, Finance, Money Circulation and Credit, Ternopil National Economic University, Ternopil, Ukraine.

13.Humeniuk, V.V. (2017), "State regulation of resort and recreational services market", Ph.D. Thesis, Economic and management of national economy, Kyiv National University of Trade and Economics, Kyiv, Ukraine. 